\title{
Factors Affecting Platelet Reactivity 2 Hours After P2Y12 Receptor Antagonist Loading in Primary Percutaneous Coronary Intervention for ST-Elevation Myocardial Infarction - Impact of Pain-to-Loading Time -
}

Ioanna Xanthopoulou, MD; Periklis Davlouros, MD; Grigorios Tsigkas, MD; Nikolaos Koutsogiannis, MD; Sotirios Patsilinakos, MD; Spyridon Deftereos, MD; George Hahalis, MD; Dimitrios Alexopoulos, MD

Background: Delay in the onset of antiplatelet action occurs in patients with ST-elevation myocardial infarction (STEMI) and is likely due to disturbed absorption. We hypothesized that patients presenting relatively late after the onset of symptoms would have faster antiplatelet action.

Methods and Results: We analyzed patient-level data from 5 studies of 207 P2Y 12 receptor antagonist-naïve patients with STEMI undergoing primary percutaneous coronary intervention ( $\mathrm{PCl})$. All patients had available platelet reactivity (PR) assessment with the VerifyNow assay (in $\mathrm{P}_{2} \mathrm{Y}_{12}$ reaction units; PRU) prior to and $2 \mathrm{~h}$ after loading. High PR (HPR) was defined as $\geq 208 \mathrm{PRU}$. Pain-to-antiplatelet loading time independently predicted PR at $2 \mathrm{~h}$ after loading: every 1 - $\mathrm{h}$ increase in pain-to-antiplatelet loading time produced a $7 \%$ decrease in $P R(P=0.001)$. Pretreatment PR, body mass index, morphine and novel $\mathrm{P}_{2} \mathrm{Y}_{12}$ receptor antagonist also affected PR $2 \mathrm{~h}$ after loading. Novel $\mathrm{P}_{2} \mathrm{Y}_{12}$ receptor antagonist use and per hour increase in pain-to-antiplatelet loading time were independently associated with lower probability for HPR with an OR $(95 \% \mathrm{Cl})$ of $0.145(0.095-0.220)$ and $0.776(0.689-0.873), \mathrm{P}<0.001$ for both (C-statistic, 0.752; 95\% Cl: 0.685-0.819).

Conclusions: In STEMI patients undergoing primary $\mathrm{PCl}$, pain-to-antiplatelet loading interval is a newly described factor affecting $\mathrm{PR}$ shortly after $\mathrm{P}_{2} \mathrm{Y}_{12}$ receptor antagonist loading, according to patient-level data pooled analysis. (Circ J 2016; 80: 442-449)

Key Words: Antiplatelet; Myocardial infarction; Pharmacology

I $\mathrm{n}$ the early phase of ST-segment elevation myocardial infarction (STEMI), platelets are highly activated and represent a main constituent of fresh thrombi. ${ }^{1}$ Rapid, potent and consistent platelet inhibition is considered mandatory in order to achieve an optimal and sustained reperfusion result. ${ }^{2-4}$ A loading dose (LD) of oral antiplatelet agent should be given adjunctive to primary percutaneous coronary intervention (PCI) as early as possible or at the time of primary PCI according to practice guidelines. ${ }^{5-8}$ Delay in the onset of antiplatelet agent effects, however, has been recently described in the first several hours following oral clopidogrel, prasugrel or ticagrelor treatment. ${ }^{9-13}$ Several factors have been implicated, with a dominant role attributed to an impaired intestinal drug absorption. This may have been caused by adrenergic activation, systemic vasoconstriction, opiates, abnormal muscular activity of the gastrointestinal tract, nausea or vomiting. ${ }^{9,13}$ In contrast, it is a common clinical perception that these conditions are very prevalent in the very early course of STEMI, while they tend to subside with time. We hypothesized that STEMI patients presenting for primary PCI relatively late after the onset of symptoms may have greater attenuation of conditions likely to impede absorption of oral antiplatelet agents, and therefore a more rapid onset of antiplatelet action might be expected with increasing onset of pain-to-antiplatelet

Received May 11, 2015; revised manuscript received October 3, 2015; accepted October 21, 2015; released online November 24, 2015 Time for primary review: 17 days

Department of Cardiology, Patras University Hospital, Patras (I.X., P.D., G.T., N.K., G.H., D.A.); Department of Cardiology, Konstantopoulio General Hospital, Athens (S.P.); and Department of Cardiology, Athens General Hospital "G. Gennimatas", Athens (S.D.), Greece

Mailing address: Dimitrios Alexopoulos, MD, FACC, FESC, Cardiology Department, Patras University Hospital, Rion 26500, Patras, Greece. E-mail: dalex@med.upatras.gr

ISSN-1346-9843 doi:10.1253/circj.CJ-15-0495

All rights are reserved to the Japanese Circulation Society. For permissions, please e-mail: cj@j-circ.or.jp 


\begin{tabular}{|c|c|c|c|c|}
\hline Study & $\mathbf{n}$ & Subjects & Study design & Treatment \\
\hline Alexopoulos et al ${ }^{12}$ & 52 & $\begin{array}{l}\text { Patients with STEMI } \\
\text { undergoing primary } \mathrm{PCI}\end{array}$ & $\begin{array}{l}\text { Prospective, single-center, } \\
\text { randomized, parallel }\end{array}$ & $\begin{array}{l}\text { Ticagrelor } 180 \mathrm{mg} \text { LD, } \\
\text { Prasugrel } 60 \mathrm{mg} \text { LD }\end{array}$ \\
\hline Alexopoulos et al ${ }^{14}$ & 36 & $\begin{array}{l}\text { Patients with STEMI } \\
\text { undergoing primary } \mathrm{PCI}\end{array}$ & $\begin{array}{c}\text { Prospective, 4-center, } \\
\text { non-randomized, sequential }\end{array}$ & $\begin{array}{l}\text { Ticagrelor } 360 \mathrm{mg} \text { LD', } \\
\text { Ticagrelor } 180 \mathrm{mg} \text { LD }\end{array}$ \\
\hline Alexopoulos et al ${ }^{15}$ & 35 & $\begin{array}{l}\text { Patients with STEMI } \\
\text { undergoing primary } \mathrm{PCI}\end{array}$ & $\begin{array}{c}\text { Prospective, 3-center, } \\
\text { non-randomized, sequential }\end{array}$ & $\begin{array}{l}\text { Prasugrel } 100 \mathrm{mg} \mathrm{LD}^{\dagger}, \\
\text { Prasugrel } 60 \mathrm{mg} \text { LD }\end{array}$ \\
\hline Alexopoulos et al ${ }^{16}$ & 10 & $\begin{array}{l}\text { Patients with STEMI } \\
\text { undergoing primary } \mathrm{PCl}\end{array}$ & $\begin{array}{l}\text { Prospective, single-center, } \\
\text { randomized, parallel }\end{array}$ & $\begin{array}{l}\text { Ticagrelor } 180 \mathrm{mg} \text { LD crushed }{ }^{\dagger} \text {, } \\
\text { Ticagrelor } 180 \mathrm{mg} \text { LD whole pils }\end{array}$ \\
\hline $\begin{array}{l}\text { Alexopoulos et al ongoing } \\
\text { study (ClinicalTrials.gov } \\
\text { NCT01961856) }\end{array}$ & 74 & $\begin{array}{l}\text { Patients with STEMI } \\
\text { undergoing primary } \mathrm{PCI}\end{array}$ & $\begin{array}{l}\text { Prospective, 3-center, } \\
\text { randomized, parallel }\end{array}$ & $\begin{array}{l}\text { Ticagrelor } 180 \mathrm{mg} \text { LD, } \\
\text { Clopidogrel } 600 \mathrm{mg} \text { LD }\end{array}$ \\
\hline
\end{tabular}

${ }^{\dagger}$ Not included in the present analysis. LD, loading dose; PCI, percutaneous coronary intervention; STEMI, ST-segment elevation myocardial infarction.

LD time. To our knowledge, no previous study has explicitly analyzed the impact of this time interval on platelet reactivity changes after antiplatelet loading. In the present study, in STEMI patients admitted for primary PCI, we analyzed factors, including onset of pain-to-antiplatelet LD time, affecting the onset of antiplatelet action, as assessed on platelet reactivity $2 \mathrm{~h}$ after oral antiplatelet agent LD.

\section{Methods}

We analyzed platelet function in $\mathrm{P}_{2} \mathrm{Y}_{12}$ receptor antagonistnaïve patients with STEMI undergoing primary PCI within $12 \mathrm{~h}$ from the onset of symptoms. We included all 207 patients treated with either clopidogrel $600 \mathrm{mg}$ or prasugrel $60 \mathrm{mg}$ or ticagrelor $180 \mathrm{mg} \mathrm{LD}$ with available platelet reactivity measurement prior to (hour 0 ) and at hour 2 after LD from 4 previously published ${ }^{12,14-16}$ and 1 ongoing study (ClinicalTrials.gov NCT02046486), in which detailed inclusion and exclusion criteria are reported (Table 1). Briefly, patients were excluded if they had a history of bleeding diathesis, chronic oral anticoagulation treatment, contraindications to antiplatelet therapy, platelet count $<100,000 / \mu 1$, hematocrit $<30 \%$, and creatinine clearance $<25 \mathrm{ml} / \mathrm{min}$. Moreover, patients with a history of stroke, weighing $\leq 60 \mathrm{~kg}$, or $>75$ years of age were excluded from prasugrel treatment. In all cases, antiplatelet LD was administered after angiography and prior to primary PCI.

Peripheral venous blood samples were drawn with a loose tourniquet through a short venous catheter inserted into a forearm vein. The first $2-4 \mathrm{ml}$ of blood was discarded to avoid spontaneous platelet activation, and blood was collected in $3.2 \%$ citrate $(1.8 \mathrm{ml}$-draw plastic Vacuette tubes; Greiner, Monroe, NC, USA). Platelet-function testing was performed with the VerifyNow P2Y 12 assay (Accumetrics, San Diego, CA, USA). Platelet reactivity results are reported in $\mathrm{P}_{2} \mathrm{Y}_{12}$ reaction units (PRU). High platelet reactivity (HPR) was defined as $\geq 208$ PRU. ${ }^{17}$

\section{Statistical Analysis}

Categorical data are presented as frequencies and group percentages. Continuous data with normal and skewed distribution are presented as mean \pm SD and median (interquartile range - IQR), respectively. Kolmogorov-Smirnov test was used to examine data distribution normality. Jonckheere-Terpstra test was used to assess platelet reactivity across quartiles of painto-antiplatelet loading time. Given that distribution of platelet reactivity in $>80 \%$ of patients in the integrated dataset was right-skewed, platelet reactivity in the overall population was

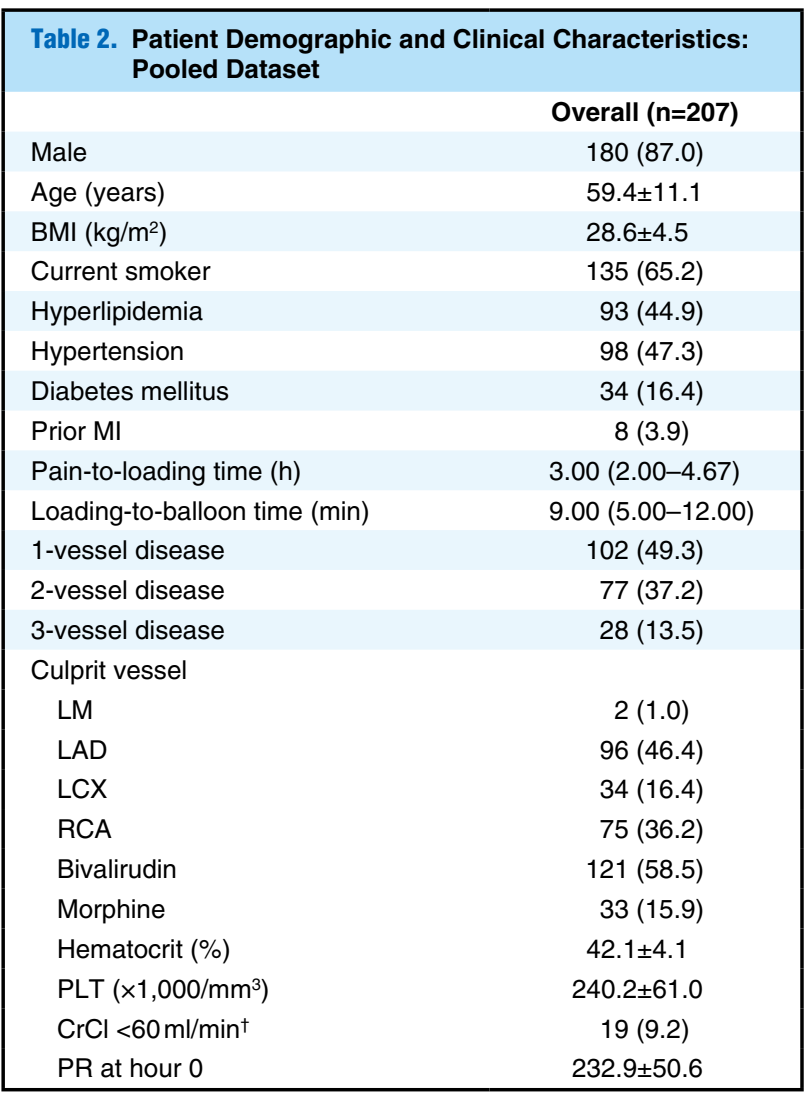

Data given as mean $\pm \mathrm{SD}$, median (IQR) or $\mathrm{n}(\%)$. ${ }^{\dagger}$ Estimated using Cockroft-Gault equation. BMI, body mass index; $\mathrm{CrCl}$, creatinine clearance; IQR, interquartile range; LAD, left anterior descending artery; LCX, left circumflex artery; LM, left main; MI, myocardial infarction; PLT, platelets; PR, platelet reactivity; RCA, right coronary artery; SD, standard deviation.

analyzed with a generalized mixed model with gamma distribution and log link. To account for within-study correlation of participants, we modeled study as a random intercept and platelet reactivity at hour 0 as a covariate. Gender, smoking status, diabetes mellitus, bivalirudin use, morphine use, and novel $\mathrm{P} 2 \mathrm{Y}_{12}$ receptor antagonist use (vs. clopidogrel) were modeled as fixed categorical variables and age (in decades), creatinine clearance (per $30 \mathrm{ml} / \mathrm{min}$ ), body mass index (BMI, 

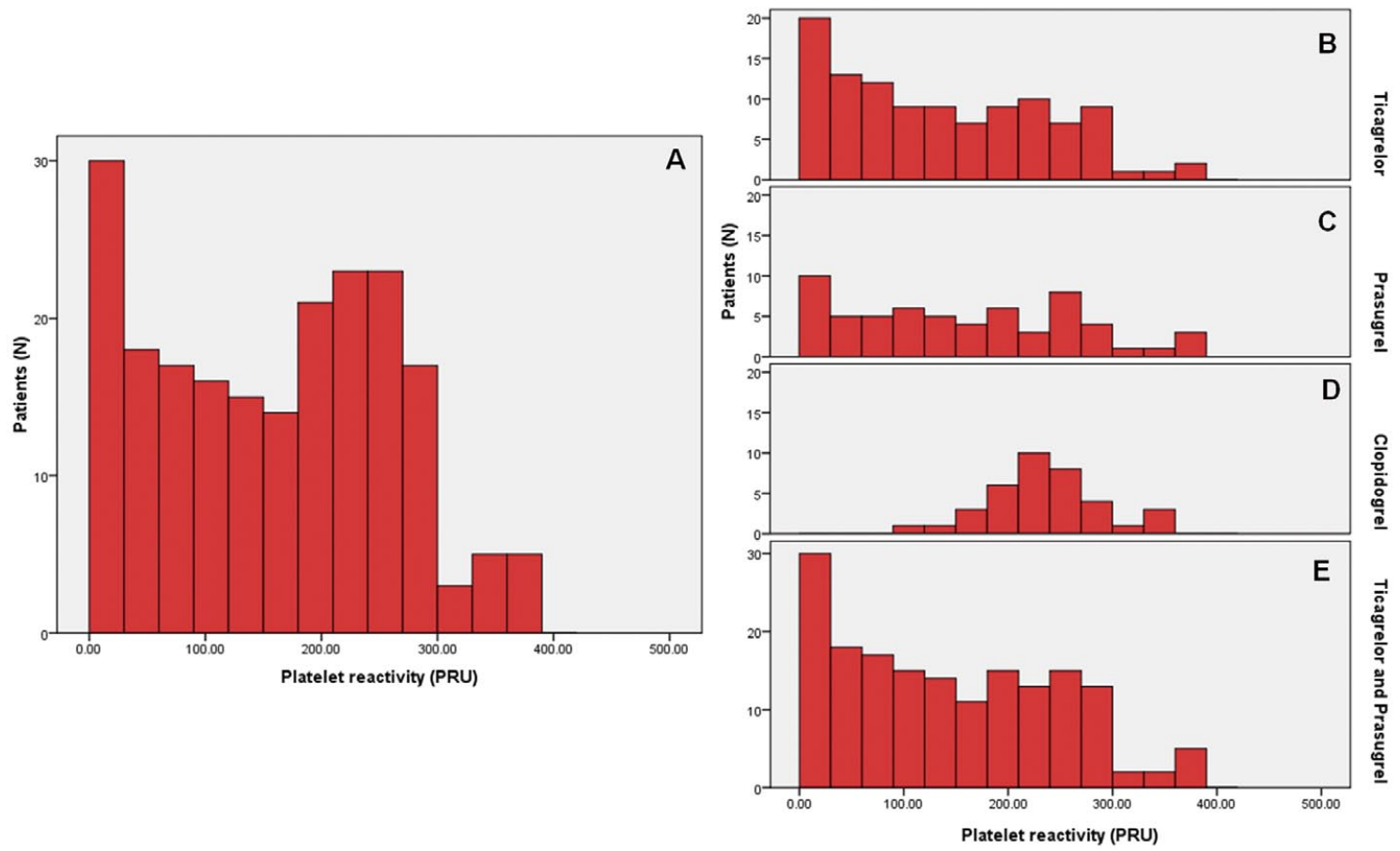

Figure 1. Distribution of platelet reactivity at hour 2 after antiplatelet loading dose in (A) the pooled population; and (B) ticagrelor, (C) prasugrel, (D) clopidogrel and (E) novel P2Y 12 receptor antagonist (ticagrelor and prasugrel)-treated patients. PRU, P2Y 12 reaction units.

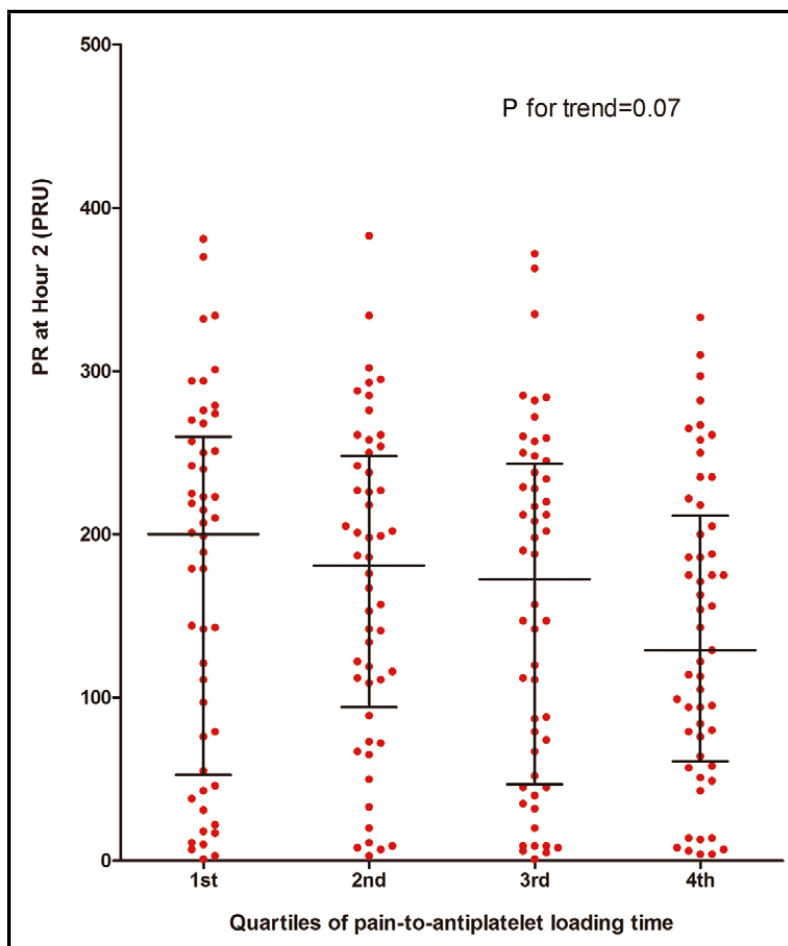

Figure 2. Individual patient platelet reactivity (PR) at hour 2 vs. quartiles of pain-to-antiplatelet loading dose time. Horizontal lines, median; error bars, interquartile range. PRU, P2Y 12 reaction units. per $5 \mathrm{~kg} / \mathrm{m}^{2}$ ) and pain-to-antiplatelet LD time (h) as continuous variables. We also performed a stratified analysis of platelet reactivity according to $\mathrm{P}_{2} \mathrm{Y}_{12}$ receptor antagonist used. To analyze platelet reactivity in clopidogrel-treated patients and in novel $\mathrm{P}_{2} \mathrm{Y}_{12}$ receptor antagonist (ticagrelor and prasugrel)treated patients, we performed generalized linear mixed (Gaussian distribution and link identity) and gamma-log modeling, respectively, adjusting for all the aforementioned variables except for type of $\mathrm{P}_{2} \mathrm{Y}_{12}$ receptor antagonist used. All coefficients resulting from gamma-log and linear models are reported in non-exponential form. To assess potential predictive factors of HPR at hour 2, we fitted a logistic regression model in a backward elimination fashion $(\mathrm{P}>0.1$ for removal criterion), with study as a random intercept and platelet reactivity at hour 0 as a covariate. Gender, smoking status, diabetes mellitus, bivalirudin use, morphine use, and novel P2 $\mathrm{Y}_{12}$ receptor antagonist use (vs. clopidogrel) were modeled as fixed categorical variables and age (in decades), creatinine clearance (per $30 \mathrm{ml} / \mathrm{min}$ ), BMI (per $5 \mathrm{~kg} / \mathrm{m}^{2}$ ) and pain-toantiplatelet LD time (in $\mathrm{h}$ ) as continuous variables. The discriminative power of the final model was tested using the C-statistic.

All tests were 2-tailed and statistical significance was considered for $\mathrm{P}<0.05$. Analysis was performed using SPSS for Windows (version 20.0; SPSS, Chicago, IL, USA) and NCSS 8 (NCSS, Kaysville, UT, USA).

Each study protocol was approved by the hospital ethics committee and was conducted according to the principles of the Declaration of Helsinki. All patients provided written informed consent before enrollment. 


\begin{tabular}{|c|c|c|c|c|}
\hline & Coefficient (SE) & $t$ & $95 \% \mathrm{Cl}$ & P-value \\
\hline Intercept & $5.068(0.531)$ & 9.551 & 4.021 to 6.114 & $<0.001$ \\
\hline PR at hour 0 (PRU) & $0.002(0.001)$ & 3.509 & 0.001 to 0.003 & 0.001 \\
\hline Male gender & $-0.179(0.100)$ & -1.786 & -0.378 to 0.019 & 0.076 \\
\hline Morphine use & $0.334(0.052)$ & 6.407 & 0.231 to 0.437 & $<0.001$ \\
\hline Bivalirudin use & $0.123(0.189)$ & 0.650 & -0.250 to 0.496 & 0.516 \\
\hline $\mathrm{CrCl}(\text { per } 30 \mathrm{ml} / \mathrm{min})^{\dagger}$ & $-0.078(0.051)$ & -1.548 & -0.178 to 0.021 & 0.123 \\
\hline Age (decades) & $0.048(0.028)$ & 1.691 & -0.008 to 0.103 & 0.092 \\
\hline BMI (per $\left.5 \mathrm{~kg} / \mathrm{m}^{2}\right)$ & $0.137(0.047)$ & 2.897 & 0.044 to 0.230 & 0.004 \\
\hline Smoking & $-0.036(0.090)$ & -0.403 & -0.213 to 0.140 & 0.687 \\
\hline DM & $0.096(0.063)$ & 1.512 & -0.029 to 0.221 & 0.132 \\
\hline Pain-to-loading time (h) & $-0.073(0.021)$ & -3.532 & -0.113 to -0.032 & 0.001 \\
\hline $\begin{array}{l}\text { Novel P2Y } 12 \text { receptor antagonist (vs. } \\
\text { clopidogrel) }\end{array}$ & $-0.580(0.037)$ & -15.515 & -0.654 to -0.507 & $<0.001$ \\
\hline
\end{tabular}

${ }^{\dagger}$ Calculated using the Cockroft-Gault formula. PRU, P2Y 12 reaction units; SE, standard error. Other abbreviations as in Tables 1,2.

\begin{tabular}{|c|c|c|c|c|}
\hline & Coefficient (SE) & $\mathbf{t}$ & $95 \% \mathrm{Cl}$ & P-value \\
\hline Intercept & $205.5(56.4)$ & 3.642 & 91.2 to 319.8 & 0.001 \\
\hline PR at hour 0 (PRU) & $0.3(0.1)$ & 2.3 & 0.04 to 0.6 & 0.03 \\
\hline Male gender & $9.6(34.5)$ & 0.3 & -60.4 to 79.6 & 0.8 \\
\hline Morphine use & $-8.5(22.0)$ & -0.4 & -53.1 to 36.0 & 0.7 \\
\hline Bivalirudin use & $-6.0(13.6)$ & -0.4 & -33.5 to 21.5 & 0.7 \\
\hline $\mathrm{CrCl}(\text { per } 30 \mathrm{ml} / \mathrm{min})^{\dagger}$ & $-2.5(8.4)$ & -0.3 & -19.5 to 14.5 & 0.8 \\
\hline Age (decades) & $4.8(8.6)$ & 0.6 & -12.7 to 22.3 & 0.6 \\
\hline BMI (per $\left.5 \mathrm{~kg} / \mathrm{m}^{2}\right)$ & $2.9(9.1)$ & 0.3 & -15.6 to 21.3 & 0.8 \\
\hline Smoking & $-32.8(14.1)$ & -2.3 & -61.4 to -4.2 & 0.03 \\
\hline DM & $42.4(15.5)$ & 2.7 & 10.9 to 73.7 & 0.009 \\
\hline Pain-to-loading time $(\mathrm{h})$ & $-12.8(3.8)$ & -3.4 & -20.4 to -5.2 & 0.002 \\
\hline
\end{tabular}

${ }^{\dagger}$ Calculated using the Cockroft-Gault formula. Abbreviations as in Tables 1-3.

\section{Results}

In total, pooled patient-level data of 207 patients from 5 studies were used for analysis (Table 1). Patient demographic and clinical characteristics listed in Table 2. Distribution of platelet reactivity at hour 2 after LD in the pooled population seems to have a bimodal pattern, being a mixture of right-skewed and Gaussian distribution (Figure 1A). Ticagrelor (52.7\% of patients in the pooled population) produced a highly right-skewed distribution; prasugrel (29.4\% of patients), a less right-skewed and more uniform distribution; and clopidogrel (17.9\% of patients), a Gaussian distribution (Figures 1B-D). Platelet reactivity in the subgroup of patients treated with novel agents (ticagrelor and prasugrel, $82.1 \%$ of patients in the pooled population) also had a right-skewed distribution (Figure 1E). There was a trend (that did not achieve statistical significance) towards decrease in platelet reactivity at hour 2 across quartiles of pain-to-antiplatelet LD time (Figure 2).

Variables affecting platelet reactivity at hour 2 after LD are listed in Table 3. Pain-to-antiplatelet LD time emerged as a factor with significant impact on platelet reactivity at hour 2 after LD. With every 1 -h increase in pain-to-antiplatelet LD time, log of platelet reactivity was decreased by 0.073 , corresponding to a $7 \%$ decrease in platelet reactivity $(\mathrm{P}=0.001)$.
Additional factors affecting platelet reactivity at hour 2 after LD in the overall population were also identified: Platelet reactivity at hour 0 had a significant influence, although with a very low effect size. BMI and morphine use had a positive effect on platelet reactivity. In particular, every 5-unit increase in BMI and morphine use resulted in a 0.137 and 0.334 increase in the log of expected platelet reactivity, respectively, corresponding to approximately a $15 \%$ and $40 \%$ increase in platelet reactivity $(\mathrm{P}=0.004$ and $\mathrm{P}<0.001$, respectively). Treatment with novel $\mathrm{P} 2 \mathrm{Y}_{12}$ receptor antagonist had a negative effect on platelet reactivity: compared with clopidogrel-treated patients, log of platelet reactivity was decreased by 0.580 , corresponding to a $45 \%$ decrease in platelet reactivity in novel $\mathrm{P} 2 \mathrm{Y}_{12}$ receptor antagonist-treated patients $(\mathrm{P}<0.001)$.

In the subgroup of clopidogrel-treated patients (Table 4), pain-to-antiplatelet LD time remained a factor that significantly affected platelet reactivity: with every 1-h increase in pain-to-antiplatelet LD time, platelet reactivity decreased by 12.8 PRU $(\mathrm{P}=0.002)$. In the subgroup of novel $\mathrm{P} 2 \mathrm{Y}_{12}$-treated patients (Table 5), pain-to-antiplatelet LD time also preserved its impact on platelet reactivity at hour 2 after LD: with every 1-h increase in pain-to-antiplatelet LD time, log of platelet reactivity was decreased by 0.076 , corresponding to a $7.3 \%$ decrease in platelet reactivity $(\mathrm{P}=0.001)$. 


\begin{tabular}{|c|c|c|c|c|}
\hline & Coefficient (SE) & $\mathbf{t}$ & $95 \% \mathrm{Cl}$ & P-value \\
\hline Intercept & $4.325(0.491)$ & 8.806 & 3.355 to 5.296 & $<0.001$ \\
\hline PR at hour 0 (PRU) & $0.002(0.001)$ & 3.886 & 0.001 to 0.003 & $<0.001$ \\
\hline Male gender & $-0.182(0.116)$ & -1.566 & -0.411 to 0.047 & 0.119 \\
\hline Morphine use & $0.377(0.089)$ & 4.213 & 0.200 to 0.554 & $<0.001$ \\
\hline Bivalirudin use & $0.167(0.204)$ & 0.821 & -0.235 to 0.570 & 0.413 \\
\hline $\mathrm{CrCl}(\text { per } 30 \mathrm{ml} / \mathrm{min})^{\dagger}$ & $-0.083(0.070)$ & -1.185 & -0.222 to 0.055 & 0.238 \\
\hline Age (in decades) & $0.057(0.025)$ & 2.261 & 0.007 to 0.106 & 0.025 \\
\hline BMI (per $\left.5 \mathrm{~kg} / \mathrm{m}^{2}\right)$ & $0.160(0.051)$ & 3.126 & 0.059 to 0.261 & 0.002 \\
\hline Smoking & $-0.017(0.094)$ & -0.177 & -0.202 to 0.169 & 0.859 \\
\hline DM & $0.100(0.098)$ & 1.019 & -0.094 to 0.293 & 0.310 \\
\hline Pain-to-loading time (h) & $-0.076(0.022)$ & -3.477 & -0.119 to -0.033 & 0.001 \\
\hline
\end{tabular}

${ }^{\dagger}$ Calculated using the Cockroft-Gault formula. Abbreviations as in Tables 1-3.

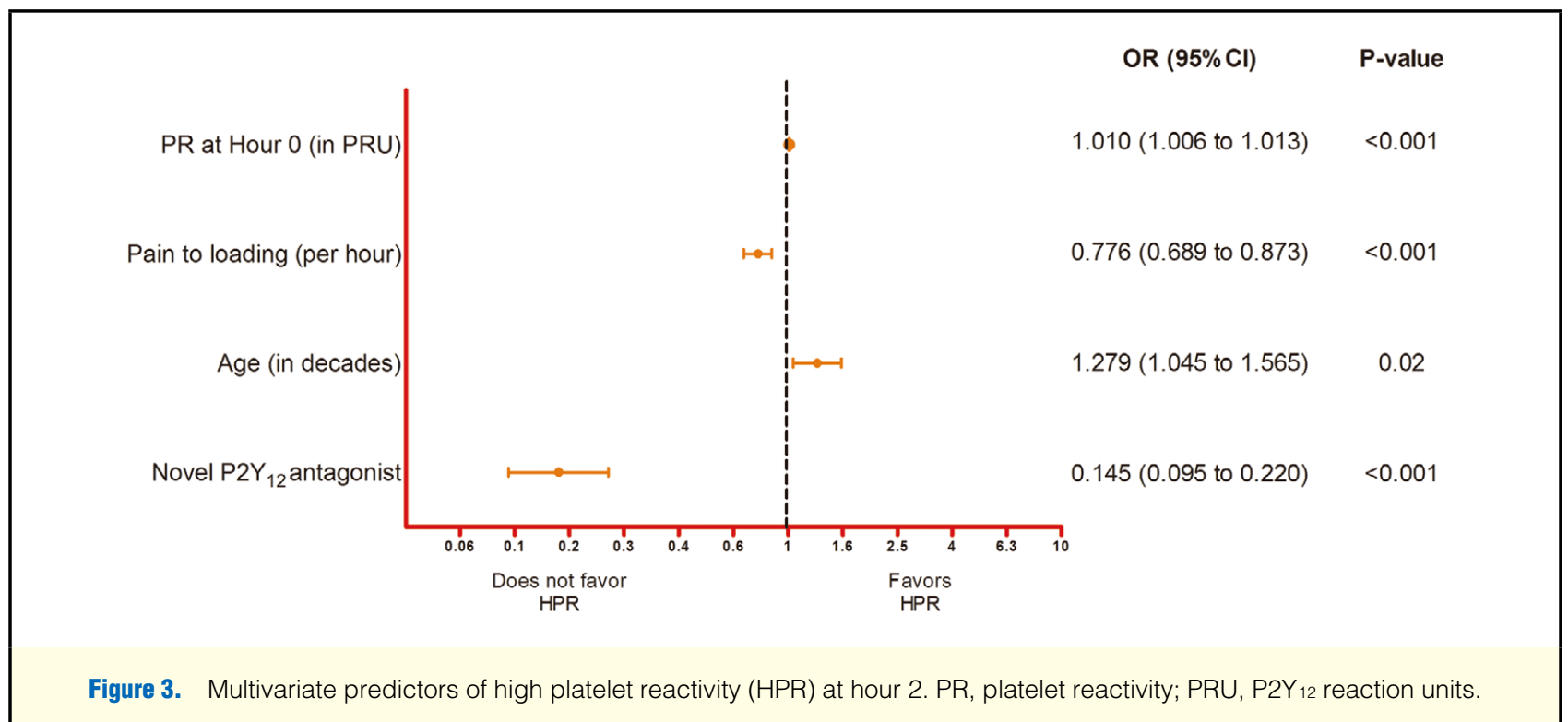

HPR rate at hour 2 was $36.7 \%$ in the overall population. On multivariate analysis (Figure 3), novel $\mathrm{P}_{2} \mathrm{Y}_{12}$ receptor antagonist use and per hour increase in pain-to-antiplatelet LD time were independently associated with lower probability for HPR, with an OR (95\% CI) of $0.145(0.095-0.220)$ and 0.776 (0.689-0.873), respectively $(\mathrm{P}<0.001$ for both in the final model, which had a good discriminative power; C-statistic, 0.752; 95\% CI: 0.685-0.819). Pre-treatment platelet reactivity (at hour 0) was also identified as an independent predictor of HPR, although with low effect size. Moreover, increased age was associated with higher probability for HPR (OR, 1.279; 95\% CI: $1.045-1.565 ; \mathrm{P}=0.02$ ).

\section{Discussion}

In the highly prothrombotic state of patients presenting with STEMI, rapid and strong platelet inhibition is most desirable. Delay in the onset of antiplatelet action has been observed after $\mathrm{P} 2 \mathrm{Y}_{12}$ receptor antagonist loading, even when using the novel antiplatelet agents prasugrel and ticagrelor, proved to have faster onset of action than clopidogrel. Various methods have been used to bridge the gap in antiplatelet activity, such as antiplatelet LD modification; prehospital treatment; cangrelor (i.v. $\mathrm{P}_{2} \mathrm{Y}_{12}$ receptor antagonist) or glycoprotein $\mathrm{IIb} / \mathrm{IIIa}$ inhibitor use. ${ }^{11,12,14-16,18-20}$ Identification of factors influencing the onset of antiplatelet action may facilitate better periinterventional platelet inhibition and subsequently improved clinical outcome. ${ }^{21}$ The present study in a large cohort of STEMI patients confirms the influence of several previously reported factors such as intrinsic platelet reactivity, specific antiplatelet agent used, BMI and morphine use, on early ( $2 \mathrm{~h}$ after LD) platelet inhibition. ${ }^{22-30}$ Most importantly, onset of pain-to-antiplatelet LD time, was identified as (a newly recognized) independent factor significantly affecting platelet reactivity shortly after antiplatelet loading in STEMI patients undergoing primary PCI. A bimodal pattern of distribution of platelet reactivity at hour 2 after LD was observed. This may be attributed to the fact that patients in the pooled population were not treated with the same $\mathrm{P} 2 \mathrm{Y}_{12}$ receptor antagonist - a major determinant of platelet reactivity - but with 3 different agents, which differ in onset of action and antiplatelet potency. Of note, in stratified analysis according to $\mathrm{P} 2 \mathrm{Y}_{12}$ receptor 
antagonist used, the effect of time remained constant across antiplatelet treatment (novel $\mathrm{P} 2 \mathrm{Y}_{12}$ receptor antagonists and clopidogrel).

Time from onset of symptoms to first medical contact and therefore potential loading with antiplatelet agents is frequently $>4$ h. ${ }^{1,31}$ This was the case in the present series as well. A more frequent occurrence of no-reflow phenomenon and a worse prognosis are well appreciated in late compared with early presenters following the onset of symptoms. ${ }^{32-34}$ In this higher risk cohort, however, we demonstrated a faster antiplatelet efficacy following a standard LD of oral $\mathrm{P} 2 \mathrm{Y}_{12}$ receptor antagonists. We assume that this earlier onset of antiplatelet action may have been caused by the diminution of conditions known to impede antiplatelet drug absorption. Increased sympathetic activation, nausea, vomiting, disturbed gastric motility and opiate use have increasingly been recognized as factors impeding oral drug absorption and contributing to delay of onset of action in relatively unstable patients. Following a high loading dose of clopidogrel, a significantly impaired bioavailability was first described by Heestermans et al in STEMI patients, as compared with healthy volunteers, and attributed to increased sympathetic drive, impaired gastric emptying, intestinal motility and absorption. ${ }^{9}$ Moreover, morphine, which is commonly used in STEMI patients, was found in a randomized, double-blind, placebo-controlled study to delay clopidogrel absorption, decrease plasma clopidogrel active metabolite, and retard and diminish its effects. ${ }^{29}$ In a randomized comparison of prasugrel with ticagrelor in STEMI patients undergoing primary PCI, morphine use was first reported by Parodi et al to be associated with delayed activity of these agents. ${ }^{13}$ These results were further confirmed in a larger cohort. ${ }^{30}$ Nevertheless, given that there is no pharmacokinetic confirmation, the basis of the potential interactions between the aforedescribed mechanisms and the present findings remains speculative.

The exact significance of the present findings is not clear. Silvain et al have described a significant influence of ischemic time on thrombi composition, resulting in a positive and a negative correlation with intracoronary thrombus fibrin and platelet content, respectively. ${ }^{1}$ An impact on the efficacy of drugs used for coronary reperfusion has been hypothesized, with a more mature thrombus likely being more resistant to antiplatelet treatment. Nevertheless, the faster action of antiplatelet agents described here may partially counteract this detrimental effect of changing thrombus composition in the early hours of STEMI. The slower onset of oral antiplatelet agent action in the very early hours may suggest a more prominent role for i.v. agents, either glycoprotein IIb/IIIa inhibitors or cangrelor, in the achievement of platelet inhibition. Moreover, the expected higher platelet inhibition $2 \mathrm{~h}$ after LD in patients presenting relatively late after the onset of symptoms raises the possibility for selection of slower acting but less potent clopidogrel in the case of concomitant high bleeding risk. This, however, should be balanced with the higher risk features of late presenters such as more frequent occurrence of no-reflow phenomenon and worst prognosis. ${ }^{32-34}$ Whether the described faster onset of antiplatelet action has any impact on bleeding frequency or severity is also unclear, given that - to our knowledge - no relationship between bleeding events and late presentation has been reported so far. The issue of the optimal timing of antiplatelet LD in STEMI patients has been recently investigated in the ATLANTIC trial, where, despite the negative primary endpoint result, the safety of pre-hospital use of ticagrelor was documented. ${ }^{19}$ Of note, morphine was the only one among the analyzed patient characteristics that affected the co-primary endpoints, with a lower occurrence in the pre-hospital group in which morphine had not been used.

With regard to other factors identified in the present study as influencing platelet reactivity $2 \mathrm{~h}$ after LD, the role of baseline (prior to any $\mathrm{P}_{2} \mathrm{Y}_{12}$ receptor antagonist treatment) platelet reactivity has been previously reported. In patients undergoing elective PCI, pretreatment platelet reactivity predicted platelet reactivity $6 \mathrm{~h}$ after treatment with thienopyridines. ${ }^{22}$ In 26 STEMI patients reported previously and included in this study, baseline platelet reactivity predicted platelet reactivity $2 \mathrm{~h}$ after ticagrelor LD, while in a large cohort of patients under ticagrelor maintenance dose, BASE (measured by VerifyNow), predicted platelet reactivity, although with a very low effect size. ${ }^{23,24}$ In line with the aforementioned reports, in an exclusively STEMI cohort described in the present study and treated with any of the 3 oral antiplatelet agents, pre-treatment platelet reactivity was positively associated with platelet reactivity $2 \mathrm{~h}$ after LD.

With increasing BMI, a higher platelet reactivity is anticipated from studies involving non-STEMI or STEMI patients beyond the acute phase. ${ }^{24-26}$ In the present analysis involving the early phase of STEMI, a similar positive association between increasing BMI and platelet reactivity $2 \mathrm{~h}$ after LD was identified. Morphine use was also positively associated with platelet reactivity $2 \mathrm{~h}$ after LD, in accordance with previous studies, most likely by delaying antiplatelet agent absorption. ${ }^{29,30}$ In the Trial to Assess Improvement in Therapeutic Outcomes by Optimizing Platelet Inhibition with PrasugrelThrombolysis in Myocardial Infarction (TRITON-TIMI) 38 platelet substudy, which established a higher platelet inhibition after $60 \mathrm{mg}$ prasugrel vs. $300 \mathrm{mg}$ clopidogrel at $1-2 \mathrm{~h}$ after-PCI ( $\geq 1 \mathrm{~h}$ after LD), only 12 STEMI patients had been included. ${ }^{27}$ The Platelet Inhibition and patient Outcomes (PLATO) PLATELET substudy, which also demonstrated a more potent platelet inhibition $2 \mathrm{~h}$ after ticagrelor $180 \mathrm{mg}$ vs. clopidogrel $300-600 \mathrm{mg}$, involved only 10 STEMI patients. ${ }^{28}$ In both studies, STEMI subgroups were not separately analyzed. In the present much larger analyzed cohort of STEMI patients, novel $\mathrm{P} 2 \mathrm{Y}_{12}$ receptor antagonist was identified as a strong predictor of lower platelet reactivity at $2 \mathrm{~h}$ after LD than clopidogrel. In line with this, in a double-blind randomized comparison in STEMI patients, lower platelet reactivity was recently reported following $60 \mathrm{mg}$ prasugrel vs. $600 \mathrm{mg}$ clopidogrel at $2 \mathrm{~h}$ after LD. ${ }^{35}$ The described effect of age on HPR also is in accordance with a previous study on platelet reactivity in patients on ticagrelor maintenance dose. ${ }^{24}$

\section{Study Limitations}

This was a retrospective analysis of the pooled data from different pharmacodynamic studies. Other factors not identified in the current analysis may be implicated, while a larger sample size may provide more precise estimates. Moreover, we cannot rule out residual bias due to overfitting. The present study design by default was not suitable or powered to reach any conclusions on clinical outcome. The lack of pharmacokinetic data does not allow elucidation of the exact mechanisms responsible for the impact of described factors, including symptom-to-antiplatelet LD time, on platelet reactivity. The HPR threshold used was obtained from receiver operating characteristic analysis in post-PCI studies involving stable or acute coronary syndrome patients, and it is not clear whether this threshold has any ability to predict upcoming events exclusively in STEMI patients undergoing primary PCI. Antiplatelet LD was not administered at first medical contact, as 
suggested by the recent European Society of Cardiology Revascularization guidelines. ${ }^{36}$ Such an approach would have posed logistic difficulties for baseline (prior to LD) blood sampling.

\section{Conclusions}

In a pooled patient-level analysis of STEMI patients undergoing primary PCI, the onset of pain-to-antiplatelet LD interval was identified as an independent determinant of platelet reactivity $2 \mathrm{~h}$ after $\mathrm{P} 2 \mathrm{Y}_{12}$ receptor antagonist loading, suggestive of a faster onset of antiplatelet action. This observation, which requires further confirmation and validation with clinical data, might improve antiplatelet treatment selection, particularly in patients for whom the balance between bleeding risk and ischemic complications is delicate.

\section{Conflict of Interest}

This study was supported by the Research Committee of the Patras University Medical School. D.A. has acted as a consultant for AstraZeneca, Boeringer Ingelheim, Bayer, and the Medicines Company, and has received remuneration from AstraZeneca.

\section{References}

1. Silvain J, Collet JP, Nagaswami C, Beygui F, Edmondson KE, Bellemain-Appaix A, et al. Composition of coronary thrombus in acute myocardial infarction. J Am Coll Cardiol 2011; 57: 13591367.

2. Alexopoulos D, Xanthopoulou I, Goudevenos J. Effects of P2 $\mathrm{Y}_{12}$ receptor inhibition in patients with ST-segment elevation myocardial infarction. Am J Cardiol 2014; 113: 2064-2069.

3. Saito S, Isshiki T, Kimura T, Ogawa H, Yokoi H, Nanto S, et al. Efficacy and safety of adjusted-dose prasugrel compared with clopidogrel in Japanese patients with acute coronary syndrome: The PRASFIT-ACS study. Circ J 2014; 78: 1684-1692.

4. Curzen N, Gurbel PA, Myat A, Bhatt DL, Redwood SR. What is the optimum adjunctive reperfusion strategy for primary percutaneous coronary intervention? Lancet 2013; 382: 633-643.

5. Alexopoulos D, Xanthopoulou I, Deftereos S, Sitafidis G, Kanakakis I, Hamilos M, et al. Contraindications/special warnings and precautions for use of contemporary oral antiplatelet treatment in patients with acute coronary syndrome undergoing percutaneous coronary intervention. Circ J 2014; 78: 180-187.

6. Lee YS, Jin CD, Kim MH, Guo LZ, Cho YR, Park K, et al. Comparison of prasugrel and ticagrelor antiplatelet effects in Korean patients presenting with ST-segment elevation myocardial infarction. Circ J 2015; 79: $1248-1254$.

7. Steg PG, James SK, Atar D, Badano LP, Blömstrom-Lundqvist C, Borger MA, et al. ESC Guidelines for the management of acute myocardial infarction in patients presenting with ST-segment elevation: The Task Force on the management of ST-segment elevation acute myocardial infarction of the European Society of Cardiology (ESC). Eur Heart J 2012; 33: 2569-2619.

8. O'Gara PT, Kushner FG, Ascheim DD, Casey DE Jr, Chung MK, de Lemos JA, et al. 2013 ACCF/AHA guideline for the management of ST-elevation myocardial infarction: A report of the American College of Cardiology Foundation/American Heart Association Task Force on Practice Guidelines: American College of Emergency Physicians; Society for Cardiovascular Angiography and Interventions. J Am Coll Cardiol 2013; 61: e78-e140, doi:10.1016/j.jacc.2012. 11.019 .

9. Heestermans AA, van Werkum JW, Taubert D, Seesing TH, von Beckerath N, Hackeng CM, et al. Impaired bioavailability of clopidogrel in patients with a ST-segment elevation myocardial infarction. Thromb Res 2008; 122: 776-781.

10. Alexopoulos D, Theodoropoulos KC, Stavrou EF, Xanthopoulou I, Kassimis G, Tsigkas G, et al. Prasugrel versus high dose clopidogrel to overcome early high on clopidogrel platelet reactivity in patients with ST elevation myocardial infarction. Cardiovasc Drugs Ther 2012; 26: 393-400.

11. Valgimigli M, Tebaldi M, Campo G, Gambetti S, Bristot L, Monti $\mathrm{M}$, et al; FABOLUS PRO Investigators. Prasugrel versus tirofiban bolus with or without short post-bolus infusion with or without concomitant prasugrel administration in patients with myocardial infarc- tion undergoing coronary stenting: The FABOLUS PRO (Facilitation through Aggrastat By drOpping or shortening Infusion Line in patients with STsegment elevation myocardial infarction compared to or on top of PRasugrel given at loading dOse) trial. JACC Cardiovasc Interv 2012; 5: 268-277.

12. Alexopoulos D, Xanthopoulou I, Gkizas V, Kassimis G, Theodoropoulos KC, Makris G, et al. Randomized assessment of ticagrelor versus prasugrel antiplatelet effects in patients with STsegment-elevation myocardial infarction. Circ Cardiovasc Interv 2012; 5: 797-804

13. Parodi G, Valenti R, Bellandi B, Migliorini A, Marcucci R, Comito $\mathrm{V}$, et al. Comparison of prasugrel and ticagrelor loading doses in ST-segment elevation myocardial infarction patients: RAPID (Rapid Activity of Platelet Inhibitor Drugs) primary PCI study. J Am Coll Cardiol 2013; 61: 1601-1606.

14. Alexopoulos D, Gkizas V, Patsilinakos S, Xanthopoulou I, Angelidis C, Anthopoulos P, et al. Double vs standard loading dose of ticagrelor: Onset of antiplatelet action in patients with STEMI undergoing primary PCI. J Am Coll Cardiol 2013; 62: 940.

15. Alexopoulos D, Makris G, Xanthopoulou I, Patsilinakos S, Deftereos S, Gkizas V, et al. Onset of antiplatelet action with high (100 mg) versus standard $(60 \mathrm{mg})$ loading dose of prasugrel in patients with ST-segment-elevation myocardial infarction undergoing primary percutaneous coronary intervention: Pharmacodynamic study. Circ Cardiovasc Interv 2014; 7: 233-239.

16. Alexopoulos D, Barampoutis N, Gkizas V, Vogiatzi C, Tsigkas G, Koutsogiannis N, et al. Crushed versus integral tablets of ticagrelor in ST-segment elevation myocardial infarction patients: A randomized pharmacokinetic/pharmacodynamic study. Clin Pharmacokinet 2015 August 28, doi:10.1007/s40262-015-0320-0.

17. Price MJ, Angiolillo DJ, Teirstein PS, Lillie E, Manoukian SV, Berger PB, et al. Platelet reactivity and cardiovascular outcomes after percutaneous coronary intervention: A time-dependent analysis of the Gauging Responsiveness with a VerifyNow P2Y12 assay: Impact on Thrombosis and Safety (GRAVITAS) trial. Circulation 2011; 124: 1132-1137.

18. Parodi G, Xanthopoulou I, Bellandi B, Gkizas V, Valenti R, Karanikas $\mathrm{S}$, et al. Ticagrelor crushed tablets administration in STEMI patients: The Mashed Or Just Integral Tablets of ticagrelOr (MOJITO) study. J Am Coll Cardiol 2015; 65: 511-512.

19. Montalescot G, van't Hof AW, Lapostolle F, Silvain J, Lassen JF, Bolognese L, et al; ATLANTIC Investigators. Prehospital ticagrelor in ST-segment elevation myocardial infarction. N Engl J Med 2014; 371: $1016-1027$.

20. Angiolillo DJ, Schneider DJ, Bhatt DL, French WJ, Price MJ, Saucedo JF, et al. Pharmacodynamic effects of cangrelor and clopidogrel: The platelet function substudy from the cangrelor versus standard therapy to achieve optimal management of platelet inhibition (CHAMPION) trials. J Thromb Thrombolysis 2012; 34: 44-55.

21. Cavender MA, Harrington RA, Stone GW, Mahaffey K, Skerjanec $\mathrm{S}$, Prats J, et al. Early benefit of cangrelor in patients undergoing PCI in CHAMPION-PHOENIX. In: ESC Barcelona 2014; abstract 5804. http://congress365.escardio.org/SubSession/3562\#.VVCAdeasXSs (accessed May 11, 2015).

22. Frelinger AL 3rd, Michelson AD, Wiviott SD, Trenk D, Neumann FJ, Miller DL, et al. Intrinsic platelet reactivity before P2Y12 blockade contributes to residual platelet reactivity despite high-level P2Y12 blockade by prasugrel or high-dose clopidogrel: Results from PRINCIPLE-TIMI 44. Thromb Haemost 2011; 106: 219-226.

23. Alexopoulos D, Xanthopoulou I, Davlouros P, Tsigkas G, Damelou A, Theodoropoulos KC, et al. Pretreatment platelet reactivity contribution to residual, post-treatment platelet reactivity in prasugreltreated and ticagrelor-treated patients. J Thromb Haemost 2013; 11: $381-384$.

24. Alexopoulos D, Xanthopoulou I, Storey RF, Bliden KP, Tantry US, Angiolillo DJ, et al. Platelet reactivity during ticagrelor maintenance therapy: A patient-level data meta-analysis. Am Heart J 2014; 168: $530-536$.

25. Wrishko RE, Ernest CS 2nd, Small DS, Li YG, Weerakkody GJ, Riesmeyer JR, et al. Population pharmacokinetic analyses to evaluate the influence of intrinsic and extrinsic factors on exposure of prasugrel active metabolite in TRITON-TIMI 38. J Clin Pharmacol 2009; 49: 984-998.

26. Wagner H, Angiolillo DJ, Ten Berg JM, Bergmeijer TO, Jakubowski JA, Small DS, et al. Higher body weight patients on clopidogrel maintenance therapy have lower active metabolite concentrations, lower levels of platelet inhibition, and higher rates of poor responders than low body weight patients. J Thromb Thrombolysis 2014; 38: 127-136.

27. Michelson AD, Frelinger AL 3rd, Braunwald E, Downey WE, 
Angiolillo DJ, Xenopoulos NP, et al; TRITON-TIMI 38 Investigators. Pharmacodynamic assessment of platelet inhibition by prasugrel vs. clopidogrel in the TRITON-TIMI 38 trial. Eur Heart J 2009; 30: $1753-1763$.

28. Storey RF, Angiolillo DJ, Patil SB, Desai B, Ecob R, Husted S, et al. Inhibitory effects of ticagrelor compared with clopidogrel on platelet function in patients with acute coronary syndromes: The PLATO (PLATelet inhibition and patient Outcomes) PLATELET substudy. $J$ Am Coll Cardiol 2010; 56: 1456-1462.

29. Hobl EL, Stimpfl T, Ebner J, Schoergenhofer C, Derhaschnig U, Sunder-Plassmann R, et al. Morphine decreases clopidogrel concentrations and effects: A randomized, double-blind, placebo-controlled trial. J Am Coll Cardiol 2014; 63: 630-635.

30. Parodi G, Bellandi B, Xanthopoulou I, Capranzano P, Capodanno D, Valenti R, et al. Morphine is associated with a delayed activity of oral antiplatelet agents in patients with ST-elevation acute myocardial infarction undergoing primary percutaneous coronary intervention. Circ Cardiovasc Interv 2014; 8: pii: e001593, doi:10.1161/ CIRCINTERVENTIONS.114.001593.

31. Puymirat E, Simon T, Steg PG, Schiele F, Guéret P, Blanchard D, et al; USIK USIC 2000 Investigators; FAST MI Investigators. Association of changes in clinical characteristics and management with improvement in survival among patients with ST-elevation myocardial infarction. JAMA 2012; 308: 998-1006.

32. Harrison RW, Aggarwal A, Ou FS, Klein LW, Rumsfeld JS, Roe MT, et al; American College of Cardiology National Cardiovascular Data Registry. Incidence and outcomes of no-reflow phenomenon during percutaneous coronary intervention among patients with acute myocardial infarction. Am J Cardiol 2013; 111: 178-184.

33. Shiomi H, Nakagawa Y, Morimoto T, Furukawa Y, Nakano A, Shirai S, et al; CREDO-Kyoto AMI investigators. Association of onset to balloon and door to balloon time with long term clinical outcome in patients with ST elevation acute myocardial infarction having primary percutaneous coronary intervention: Observational study. BMJ 2012; 344: e3257, doi:10.1136/bmj.e3257.

34. Hannan EL, Zhong Y, Jacobs AK, Holmes DR, Walford G, Venditti FJ, et al. Effect of onset-to-door time and door-to-balloon time on mortality in patients undergoing percutaneous coronary interventions for ST-segment elevation myocardial infarction. Am J Cardiol 2010; 106: $143-147$

35. Zeymer U, Mochmann HC, Mark B, Arntz HR, Thiele H, Diller F, et al. Double-blind, randomized, prospective comparison of loading doses of $600 \mathrm{mg}$ clopidogrel versus $60 \mathrm{mg}$ prasugrel in patients with acute ST-segment elevation myocardial infarction scheduled for primary percutaneous intervention: The ETAMI trial (early thienopyridine treatment to improve primary PCI in patients with acute myocardial infarction). JACC Cardiovasc Interv 2015; 8: 147-154.

36. Windecker S, Kolh P, Alfonso F, Collet JP, Cremer J, Falk V, et al. 2014 ESC/EACTS Guidelines on myocardial revascularization: The Task Force on Myocardial Revascularization of the European Society of Cardiology (ESC) and the European Association for CardioThoracic Surgery (EACTS), Developed with the special contribution of the European Association of Percutaneous Cardiovascular Interventions (EAPCI). Eur Heart J 2014; 35: 2541-2619. 